\section{Dr. Keystone, et al, reply}

\section{To the Editor:}

We thank Dr. Abeles for his interest ${ }^{1}$ in our article ${ }^{2}$. Our analysis extends earlier observations of sustained inhibition of progressive joint damage ${ }^{3}$.

As stated in our article, the study was a posthoc analysis evaluating patients with an initial response [ $\geq 20 \%$ reduction in both swollen joint count (SJC) and tender joint count (TJC)] to rituximab (RTX) and who were eligible to receive repeat treatment courses based on the physician's determination of clinical need and evidence of active disease (defined as both SJC and TJC $\geq 8$ ). The minimum re-treatment interval was 24 weeks following course 1 and 16 weeks for course 2 and all subsequent courses although, as mentioned in the article, median treatment intervals among patients with repeat courses were 0.98 years (courses $1-2 ; n=317), 1.06$ years (courses $2-3 ; n=259), 1.02$ years (courses $3-4 ; n=195$ ), and 0.91 years (courses $4-5 ; n=122$ ). Therefore, interpretation of data from course 2 onward should take biases introduced with this study design into consideration.

From course 2 onward, the dropout rate was about $10 \%$ for all subsequent courses, a value consistent with that reported for other biologic therapies ${ }^{4,5,6}$. We agree with Dr. Abeles that knowing the number of dropouts due to insufficient response is important. Unfortunately, withdrawal reasons were not reported in granular detail in the REFLEX study. All reasons other than adverse events were simply classified as "other."

To address Dr. Abeles's comment about efficacy in patients who withdrew from the study or were not re-treated for other reasons, we conducted a posthoc analysis of the mean change in Disease Activity Score-erythrocyte sedimentation rate (DAS-ESR) at Week 24 after courses 2-4 for those patients who received further courses of RTX versus those who did not. Data are shown as observed and compare clinical efficacy responses of patients with $(\mathrm{W})$ or without $(\mathrm{W} / \mathrm{O})$ receipt of subsequent courses, to evaluate the potential selection bias. We found that the mean change in DAS-ESR was comparable at Week 24 after courses 2-4 for those patients who received a subsequent RTX treatment versus those who did not (Table 1). Thus those patients who had not received a subsequent course were not necessarily nonresponders. Some patients had withdrawn for "other reasons" while others remained in their current treatment course beyond 24 weeks, without the need for subsequent treatment at that time [one might assume that for these patients the reason for not getting re-treatment may in part have been due to reaching stable disease/control of rheumatoid arthritis (RA) symptoms]. These observations were confirmed by a last observation carried forward sensitivity analysis. When the last DAS value for dropouts was included, the overall change in RA disease activity of those who did not receive a subsequent course was comparable to those who were re-treated (data not shown).

Similarly, a "within-patient within-visit" sensitivity analysis of patients who did receive all 5 courses of treatment and had 24-week data available after each course demonstrated a continual improvement in DAS LDA and remission out to course 5, accompanied by sustained American College of Rheumatology/European League Against Rheumatology responses.
Our data reflect real-life clinical practice, where a physician would not actively re-treat nonresponders or those with an insufficient therapeutic response, but would treat patients demonstrating response to previous treatment. This is particularly true of RTX where a course of treatment has an effect over the subsequent 6-month period.

Acknowledging the limitations inherent in a retrospective efficacy analysis of an open-label study, these data confirm RTX as an effective longterm treatment option in a refractory RA population and are helpful to clinicians.

EDWARD C. KEYSTONE, MD, FRCP(C), Director, The Rebecca MacDonald Centre for Arthritis and Autoimmune Disease, Mount Sinai Hospital, and Professor of Medicine, University of Toronto, Toronto, Ontario, Canada; STANLEY B. COHEN, MD, Medical Director, Metroplex Clinical Research Center, Dallas, Texas, USA; PAUL EMERY, MA, MD, FRCP, Clinical Director, University of Leeds and Leeds Teaching Hospitals, Leeds, UK; JOEL M. KREMER, MD, Rheumatologist, Albany Medical College, Albany, New York, USA; MAXIME DOUGADOS, MD, Professor of Rheumatology, René Descartes University, Paris, France; JAMES E. LOVELESS, MD, Principal Investigator, St. Luke's Rheumatology, Boise, Idaho, USA; CAROL CHUNG, PhD, Associate Director, Biostatistics; PAMELA WONG, MPh, Biostatistician, Genentech Inc., South San Francisco, California, USA; PATRICIA B. LEHANE, PhD, BSc (Hons), Clinical Scientist; HELEN TYRRELL, BSc, Senior Clinical Scientist, Roche Products Limited, Welwyn Garden City, UK. Address correspondence to Dr. Keystone, Rebecca MacDonald Centre for Arthritis and Autoimmune Diseases, Mount Sinai Hospital, The Joseph and Wolf Lebovic Building, 2nd Floor, Room 2-006, Box 4, 60 Murray Street, Toronto, ON M5G 1X5, Canada.

E-mail: edkeystone@mtsinai.on.ca

\section{REFERENCES}

1. Abeles AM. Five-year data from the REFLEX Study: a different interpretation. J Rheumatol 2013;40:732.

2. Keystone EC, Cohen SB, Emery P, Kremer JM, Dougados M, Loveless JE, et al. Multiple courses of rituximab produce sustained clinical and radiographic efficacy and safety in patients with rheumatoid arthritis and an inadequate response to 1 or more tumor necrosis factor inhibitors: 5-year data from the REFLEX study. J Rheumatol 2012;39:2238-346.

3. Cohen SB, Keystone E, Genovese MC, Emery P, Peterfy C, Tak $\mathrm{PP}$, et al. Continued inhibition of structural damage over 2 years in patients with rheumatoid arthritis treated with rituximab in combination with methotrexate. Ann Rheum Dis 2010;69:1158-61.

4. Bombardieri S, Ruiz AA, Fardellone P, Geusens P, McKenna F, Unnebrink K, et al; Research in Active Rheumatoid Arthritis (ReAct) Study Group. Effectiveness of adalimumab for rheumatoid arthritis in patients with a history of TNF-antagonist therapy in clinical practice. Rheumatology 2007;46:1191-9.

5. Emery P, Keystone E, Tony HP, Cantagrel A, van Vollenhoven R, Sanchez A, et al. IL-6 receptor inhibition with tocilizumab

Table 1. Mean change in DAS28-ESR by course and by re-treatment status.

\begin{tabular}{|c|c|c|c|c|c|c|}
\hline & $\begin{array}{c}\text { Course } 3 \\
\mathrm{n}=235\end{array}$ & $\begin{array}{c}\text { Course } 3 \\
\mathrm{n}=40\end{array}$ & $\begin{array}{c}\text { Course } 4 \\
\mathrm{n}=176\end{array}$ & $\begin{array}{c}\text { Course } 4 \\
\mathrm{n}=48\end{array}$ & $\begin{array}{c}\text { Course } 5 \\
\mathrm{n}=109\end{array}$ & $\begin{array}{c}\text { Course } 5 \\
n=48\end{array}$ \\
\hline at Week $24^{*}$, mean $(\mathrm{SD})$ & $-2.68(1.39)$ & $-2.87(1.07)$ & $-2.88(1.44)$ & $-3.36(1.38)$ & $-2.94(1.58)$ & $-3.10(1.50)$ \\
\hline
\end{tabular}

* Relative to baseline value at the initial rituximab treatment. DAS28-ESR: Disease Activity Score in 28 joints-erythrocyte sedimentation rate; W: with (received subsequent treatment course); W/O: without (did not receive subsequent treatment course). 
improves treatment outcomes in patients with rheumatoid arthritis refractory to anti-tumour necrosis factor biologicals: results from a 24-week multicentre randomised placebo-controlled trial. Ann Rheum Dis 2008;67:1516-23.

6. Schiff M, Keiserman M, Codding C, Songcharoen S, Berman A, Nayiager $\mathrm{S}$, et al. Clinical response and tolerability to abatacept in patients with rheumatoid arthritis previously treated with infliximab or abatacept: open-label extension of the ATTEST Study. Ann Rheum Dis 2011;70:2003-7.

J Rheumatol 2013;40:5; doi:10.3899/jrheum.130175 